\title{
The Use of Innovative Technologies to Ensure the Economic Security of Russia in the Context of Globalization
}

\author{
Irina Zhulega ${ }^{1, *}$, Evelina Sycheva ${ }^{2}$, and Alexandr Samoylov ${ }^{1}$ \\ ${ }^{1}$ State University of Aerospace Instrumentation, Institute of Enterprinership Technologies, Department of High-Tech Sistems \\ Security, Bolshaya Morskaya str. 67, Saint Petersburg, 190000, Russia. \\ ${ }^{2}$ Saint-Petersburg University of State Fire Service of Emercom of Russia, Moscow Avenue, 149, St. Petersburg, 196105, \\ Russia.
}

\begin{abstract}
.
Research background: Global competition constantly sets new goals for each state in the field of economic security. The globalization process covers all new areas of activity and technology. To ensure economic security, in addition to information and financial technologies, innovative technologies are joining. In order to manage innovative development, scientific and methodological approaches are necessary, which is the current background of this work.

Purpose of the article: The purpose of the study is to analyze and evaluate the use of innovative technologies to ensure the economic security of Russia in the context of globalization changes. The objective of the study is a comparative assessment of the dynamics of innovative development of Russia and the leading countries at the global level.

Methods: As a scientific and methodological approach to monitoring and analyzing the level of development of innovative processes to ensure economic security, based on a study of available statistical sources, it is proposed to use indicators - Global Innovation Index (GII) 2019.

Findings \& Value added: Globalization and economic security affect all aspects of the economy. Economic security can be considered as a process of maintaining a state, the signs of which correspond to economic security in the context of globalization changes. Global indices of innovative development make it possible to assess the level of development of modern processes in the field of economic security and determine strategic priority development vectors in the future in order to strengthen the country's economic positions and competitiveness on a global level.
\end{abstract}

Keywords: economic security; globalization; innovative technologies

JEL Classification: $F 52 ; F 63 ; O 320$

\section{Introduction}

In today's global economic activity, it is necessary to understand how to determine the world economy requirements, what impact can and should be expected if these requirements are met [1]. Innovative technologies are one of the key and most promising competition areas for economic influence between countries in the $21 \mathrm{st}$ century. The country`s positioning as competitive ensures its economic security.

Global competition sets completely new goals at the state's level in the field of economic security assurance. National competitiveness, conditioned by socio-economic and political factors, ultimately determines the society well-being level that can be achieved by economic growth and investment in innovation, which are a strategic growth factor. "Based on historical experience, each state, under the influence of changing geo-informational factors, in order to accelerate socio-economic development, has to introduce new or change old society institutions" [2]. With exhaustion of growth opportunities for each technological wave and change in the

\footnotetext{
* Corresponding author: zhulega@mail.ru
} 
structure of demand for scientific discoveries and inventions, there is a need for fundamentally new technologies, which competitive selection forms the basis of new technological trajectories [3].

Thus, competitiveness is now directly related to the introduction of innovations that ensure the ability to implement advanced technologies for maintaining a competitive advantage and move towards even higher added value. This means that maintaining global competitiveness requires constant investment in research institutions capable of generating the basic knowledge needed to enhance science, research and technological development [4].

Countries that are able to adapt innovative technologies to the new globalization demands will significantly strengthen their economic positions and thereby economic security, which is always relevant [5]. The most important component of adaptation is to achieve a balance between the strategic, tactical and operational goals of the system and its real capabilities, determined by forecasts of market situation and actions of competitors. Stable success can be achieved only by its planning and result predicting [6]. The main implementation form of innovative development management is strategic planning, which is becoming increasingly important due to changes in institutional framework after adoption of the Federal Law "On Strategic Planning in the Russian Federation" [7].

The purpose of this article is to assess the use of innovative technologies to ensure economic security, taking into account current global changes and their future forecasts.

\section{Development level assessment methodology of innovative processes to ensure economic security}

The economic security system effectiveness should be ensured using objective matrix of parameters and criteria for functioning of the state's economic system [8]. The use level measurement methodology of innovative technologies in order to ensure economic security is reflected in developing and using of system of indicators. The analysis of economic security in the context of globalization is based on the consideration of indicators - the indices of innovative development Global Innovation Index (GII) 2019 [9]. 


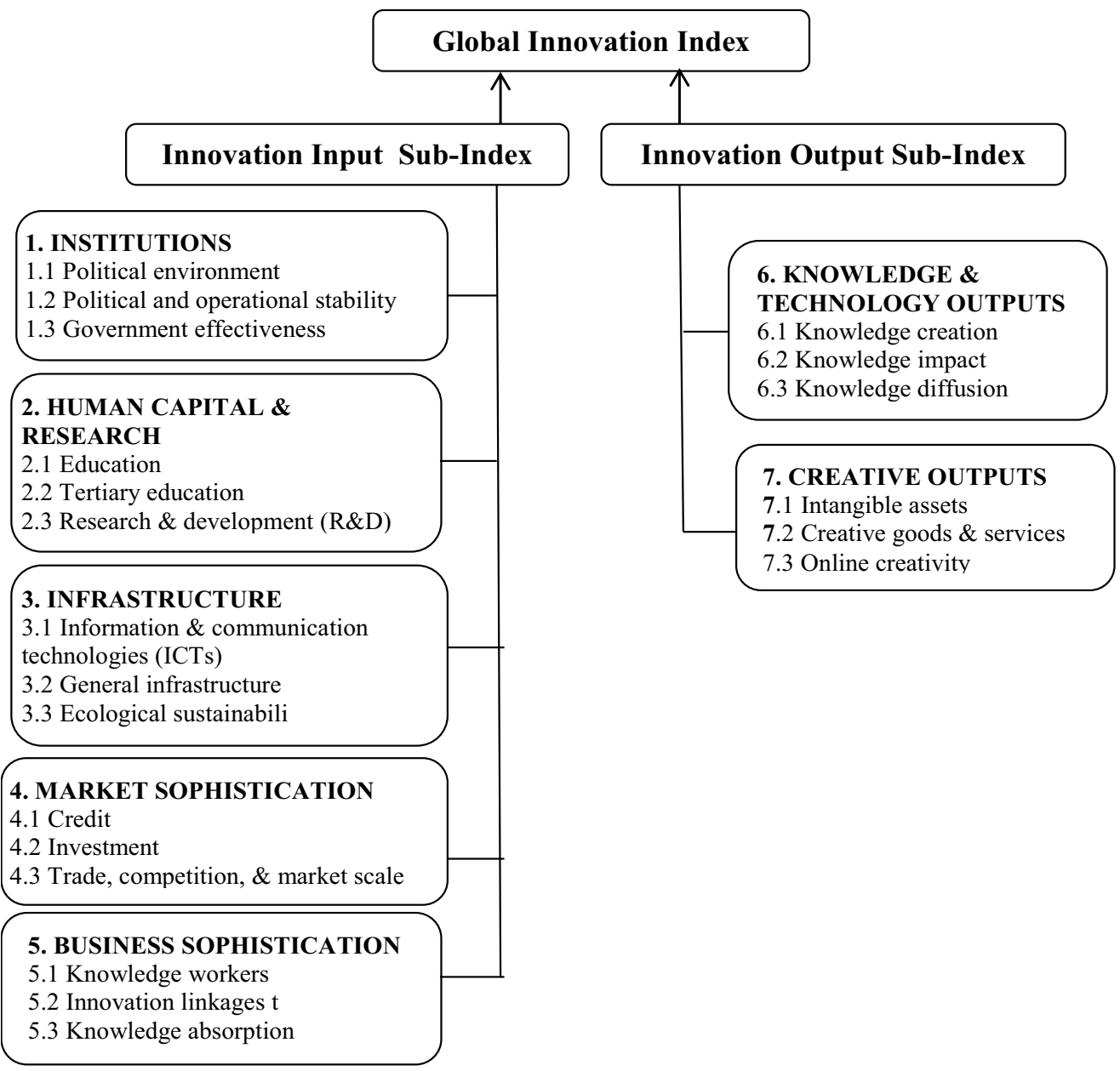

Fig. 1. Framework of the Global Innovation Index 2019.

The GII rating has been compiled by Consortium of Cornell University (USA), INSEAD Business School (France) and the World Intellectual Property Organization since 2007. On behalf of Russia, the GII Advisory Council includes and participates in the methodological support of the research, HSE Professor Leonid Gokhberg [10]. The GII-2019 ranking covers 129 countries, which together generate 96.8\% of global GDP. These countries are home to $91.8 \%$ of the world's population. GII-2019 includes indicators of innovation activity, which are grouped into seven main areas, covering elements of the national economy: institutions, human capital, infrastructure, market development, business development, technology and economy and knowledge economy development, development of creative activities [11]. Each direction (pillar) is divided into three sub-pillars, each of which consists of separate indicators, totaled up of 80 indicators (Fig. 1).

The sub-index of innovation resources is formed from totality of variables of the first five directions; the subindex of innovation results is formed based on indicators of sixth and seventh directions. The final GII rating is calculated as the average of the two sub-indices [12].

\section{Results: assessment and analysis of innovative development in Russia}

The Russia is ranked 46th in the overall GII-2019 ranking. The ranking results according to the general index of innovative activity of the ten leading countries and Russia are clearly shown in Figure 2. 


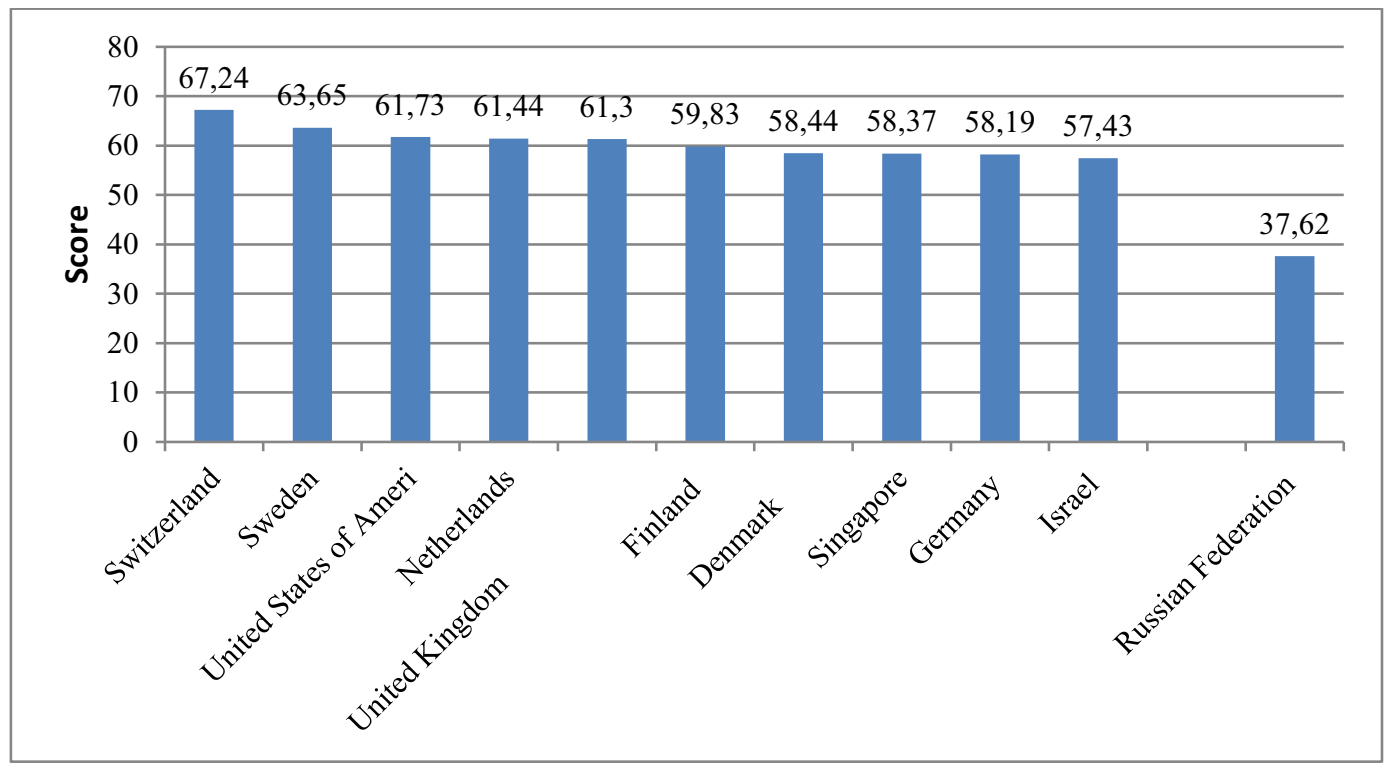

Fig. 2. Indicators of level of innovative development of countries in the GII 2019 system. Source: author according to the Global Innovation Index (GII) 2019 [9].

In 2019, the Russia falls into the group of countries "with level of GDP per capita above the average", ranking 6th among them among 34 countries, and among European countries 31 st out of 39 countries. From 2015 to 2019, the Russian Federation improves its position on the Input rank sub-index, but the position on the Output rank sub-index has deteriorated (Table 1).

Table 1. Dynamics of the Russian Federation positions in the GII 2015-2019.

\begin{tabular}{|c|c|c|c|}
\hline Years & GII & Input rank & Output rank \\
\hline 2015 & 48 & 52 & 49 \\
\hline 2016 & 43 & 44 & 47 \\
\hline 2017 & 46 & 43 & 51 \\
\hline 2018 & 46 & 42 & 58 \\
\hline 2019 & 46 & 41 & 59 \\
\hline
\end{tabular}

Based on globalization prerequisites and modernization opportunities, according to Western experts, the Russian economy can be attributed to the catching up model [13]. The Russia's lag behind the leading countries in the Global Innovation Index ratings is associated with the emergence of whole range of risks that must be overcome. All this causes the need to create the risk management system with engaging of specialists for risk management [14]. The improvement of innovative indicators is influenced by set of methods of analysis and elimination of risk factors, combined into the system of strategic planning, monitoring and corrective actions [15]. The main provisions of implementation of the strategic national priorities of the Russian Federation in the field of economic security assuramce are reflected in the Strategy of Economic Security of the Russian Federation for the period up to 2030 [16]. It assumes orientation to the main provisions of innovation strategy, which highlights the implemenatation goals, objectives and stages.

According to the GII-2019 rating, it may be assessed strengths and weaknesses of the Russia's innovation sphere (Table 2).

Table 2. Analysis of Russia's Strengths and Weaknesses in GII-2019

\begin{tabular}{|l|c|c|c|}
\hline \multicolumn{2}{|c|}{ Strengths } & \multicolumn{2}{c|}{ Weaknesses } \\
\hline Index & Rank & Index & Rank \\
\hline 2. HUMAN CAPITAL \& RESEARCH & 23 & $\begin{array}{c}1.1 .1 \text { Political and operational } \\
\text { stability }\end{array}$ & 91 \\
\hline
\end{tabular}




\begin{tabular}{|c|c|c|c|}
\hline 2.1.4 PISA scales in reading, maths, \& science & 26 & 1.2 Regulatory environment & 95 \\
\hline 2.1.5 Pupil-teacher ratio, secondary & 15 & 1.2.1 Regulatory quality & 103 \\
\hline 2.2 Tertiary education & 14 & 1.2.2 Rule of law & 111 \\
\hline 2.2.1 Tertiary enrolment, $\%$ gross & 17 & 3.3 Ecological sustainability & 101 \\
\hline 2.2.2 Graduates in science \& engineering & 10 & 3.3.1 GDP/unit of energy use & 113 \\
\hline 2.3 Research \& development (R\&D) & 30 & $\begin{array}{l}\text { 3.3.3 ISO 14001 environmental } \\
\text { certificates/bn PPP\$ GDP }\end{array}$ & 112 \\
\hline 2.3.1 Researchers, FTE/mn pop & 33 & $\begin{array}{l}\text { 4.1.3 Microfinance gross loans, } \% \\
\text { GDP }\end{array}$ & 73 \\
\hline 2.3.2 Gross expenditure on $\mathrm{R} \& \mathrm{D}, \%$ GDP & 33 & 4.2 Investment & 102 \\
\hline 2.3.3 Global R\&D companies, avg. exp. top 3, mn US\$ & 40 & & \\
\hline 2.3.4. QS university ranking, average score top $3 *$ & 24 & & \\
\hline 3.1 Information \& communication technologies(ICTs) & 29 & & \\
\hline 3.1.1 ICT access & 51 & & \\
\hline 3.1.2 ICT use & 45 & & \\
\hline 3.1.3 Government's online service & 25 & & \\
\hline 3.2.1 Electricity output, GWh/mn pop & 28 & & \\
\hline 3.1.4 E-participation & 23 & & \\
\hline 4.3 Trade, competition, \& market scale & 11 & & \\
\hline 4.3.3 Domestic market scale, bn PPP\$ & 6 & & \\
\hline 5. BUSINESS SOPHISTICATION & 35 & & \\
\hline 5.1 Knowledge workers & 25 & & \\
\hline 5.1.1 Knowledge-intensive employment, $\%$ & 18 & & \\
\hline 5.1.3 GERD performed by business, $\%$ GDP & 31 & & \\
\hline 5.1.5 Females employed w/advanced degrees, $\%$ & 7 & & \\
\hline 5.3 Knowledge absorption & 32 & & \\
\hline 5.3.1 Intellectual property payments, $\%$ total trade & 18 & & \\
\hline 5.3.5 Research talent, $\%$ in business enterprise & 27 & & \\
\hline 6.1 Knowledge creation & 30 & & \\
\hline 6.1.1 Patents by origin/bn PPP\$ GDP & 20 & & \\
\hline 6.1.3 Utility models by origin/bn PPP\$ GDP & 8 & & \\
\hline 6.1.5 Citable documents H-index & 22 & & \\
\hline 6.3.1 Intellectual property receipts, $\%$ total trade & 39 & & \\
\hline
\end{tabular}

As can be seen from this Table, the country's competitive advantages include: "Domestic market scale, bn PPP \$" - 6th place, "Females employed w/advanced degrees" - 7th place, "Utility models by origin/bn PPP \$ 
GDP" - 8th place. The top ten includes the indicator "Graduates in science \& engineering". Among the weaknesses of the Russia`s innovation system, it should be noted: "GDP/unit of energy use" - 113th place, "ISO 14001 environmental certificates/bn PPP\$ GDP" - 112th place, "Rule of law", "ISO 9001 quality certificates/bn PPP\$ GDP" - 111th place.

\section{Discussions}

Development and sustainability are important components of economic security. Increasing competitiveness, introducing innovative technologies are necessary parts of development, the formation of economic security of enterprises, industries, states. The competitiveness management, carried out by increasing the innovative potential, is reduced to assessing and analyzing the indicators of innovative activity that increase or decrease competitiveness for selection and implementation of the appropriate strategy. The Global Innovation Index (GII) is widely recognized as driver of economic growth and development. Its goal is to provide insightful data about innovation and to help countries assess innovation performance and make informed innovation policy decisions to improve competitiveness and economic security in a global world. The global competition places higher demands for the development of country's innovation strategy than it does for domestic innovation strategy.

\section{Conclusion}

Thus, by the main direction of development of national economy the competitive production based on of modern innovative technologies has to be developed. It is necessary to adapt the domestic competitive strategy to situation at international scale, as preferences and purchasing behavior in different countries differ from each other. The countries of the world differ in the intensity of competition, factors influencing the development of industry and other features. Thus, the need to adapt to the market conditions of different countries is one of the most important factors that complicate competition and ensure economic security in the world market. The main task is to find an optimal balance between adaptation to the market situation of each country and ensuring competitive prices and costs through the implementation of innovative technologies.

\section{References}

1. Novikov A. V., Gregova, E. (2017). Institution features of economic development during globalization. In T. Kliestik (Ed.), Proceedings of the $17^{\text {th }}$ International Scientific Conference of Globalization and its Socio-Economic consequences, part IV (pp. 1757-1764). Zilina: University of Zilina.

2. Bierbrauer, F.J., Boyer, P.C. (2016). Efficiency, Welfare, and Political Competition. The Quarterly Journal of Economics, 131(1), 461-518.

3. Sycheva, E., Budagov, A., Novikov, A. (2020). Urban infrastructure development in a global knowledge-based economy. SHS Web of Conferences, 74, 03013.

4. Franzi, S. (2018). The Great Convergence: Information Technology and the New Globalization. Journal of Politics, 80(1), 23-24.

5. Des Jardine M, Bansal P, Yang Y. (2019) Bouncing Back: Building Resilience Through Social and Environmental Practices in the Context of the 2008 Global Financial Crisis. Journal of Management, 45(4), 1434-1460.

6. Bernstein, A., Gustafson, M. T., Lewis, R. (2019). Disaster on the horizon: The price effect of sea level rise. Journal of Financial Economics, 134(2), 253-272.

7. Lugovskoy, R. A., Sycheva, E. V. (2014). The need to form mechanisms for assessing the effectiveness of state strategic planning. International Technical and Economic Journal, 5, 7-13.

8. Peng, M. W. (2001). The resource-based view and international business. Journal of Management, 27(6), 803-829.

9. Global Innovation Index. (2020, June 5). Retrieved from: https://www.globalinnovationindex.org

10. Kopczuk, W., Saez, E., Song, J. (2010). Earnings Inequality and Mobility in the United States: Evidence from Social Security Data Since 1937. The Quarterly Journal of Economics, 125(1), 91-128.

11. Jacobs, H., Müller, S. (2020). Anomalies across the globe: Once public, no longer existent? Journal of Financial Economics, 135(1), 213-230. 
12. Broner, F., Ventura, J. (2016). Rethinking the Effects of Financial Globalization. The Quarterly Journal of Economics, 131(3), 1497-1542.

13. Armin, F., Becker, A., Dohmen, T., Enke, B., Huffman, D. (2018). Uwe Sunde Global Evidence on Economic Preferences. The Quarterly Journal of Economics, 133(4), 1645-1692.

14. Marano V, Arregle J.-L., Hitt M. A., Spadafora E., Van Essen, M. (2016). Home Country Institutions and the Internationalization-Performance Relationship: A Meta-Analytic Review. Journal of Management, 42(5), 1075-1110.

15. Tharenou P., Kulik C. T. (2020). Skilled Migrants Employed in Developed, Mature Economies: From Newcomers to Organizational Insiders. Journal of Management, 46(6), 1156-1181.

16. Putin, V. V. (2017, May 13). On the Strategy of the Economic Security of the Russian Federation over the Period up to 2030. The Russian Federation Presidential Decree No. 208. Retrieved from: https://www.prlib.ru/en/node/681513. 